\title{
PENGGUNAAN PLAT TEMBAGA BERCOATING NIKEL SEBAGAI FILTER GAS BUANG KENDARAAN
}

\author{
Sunan Bukhori Ikhwan Nasrullah ${ }^{1}$
}

\begin{abstract}
ABSTRAK
Seiring dengan perkembangan teknologi transportasi maka kami melakukan pengujian untuk membantu mengatasi masalah terhadap pencemaran udara dengan pendekatan dan pemanfaatan teknologi rekayasa. Teknologi rekayasa yang digunakan untuk mengurangi pencemaran udara akibat emisi gas buang kendaraan dengan cara pemasangan catalytic converter pada saluran gas buang. Dalam hal ini penelitian menggunakan bahan katalis tembaga $(\mathrm{Cu})$ dan tembaga lapis nikel $(\mathrm{Cu} * \mathrm{Ni})$ dengan variasi putaran mesin. Penelitian menggunakan bahan katalis tembaga mampu menurunkan emisi gas buang karbonmonoksida (CO) dan hidrokarbon (HC). Penelitian ini juga meneliti karakteristik material tembaga sebelum pemakaian dan setelah pemakaian yang digunakan untuk mereduksi emisi gas buang, tujuan uji karakteristik material tembaga yang dilakukan dengan menggunakan SEM dan EDX agar dapat mengetahui perubahan unsur material sebelum pemakaian dan sesudah pemakaian.
\end{abstract}

Kata Kunci: Filter Gas Buang, Temaga, Nikel, Pelapisan, Gas Monoksida.

\section{PENDAHULUAN}

Udara merupakan campuran beberapa kandungan gas. Tetapi terdapat juga gas yang berdampak negatif bagi manusia dan lingkungan. Gas yang berdampak negatif ini diakibatkan adanya pencemaran udara dari industri maupun transpotasi, seperti asap cerobong pabrik maupun asap kendaraan. Gas buang kendaraan merupakan salah satu polutan atau sumber pencemaran udara yang relatif besar. Udara polutan ini mengandung racun yang berbahaya bagi kesehatan manusia, terutama gas karbon monoksida (CO). Gas karbon monoksida (CO) ini merupakan salah satu sebab utama keracunan yang paling umum bagi kesehatan manusia. Standar emisi gas buang yang sering diukur dan dipantau dengan kandungan gas tertentu, yaitu senyawa hidrokarbon (HC), karbon monoksida (CO), karbon dioksida (CO2), oksigen (O2) dan nitrogen dioksida (NO2). Untuk mengetahui konsentrasi emisi gas buang maka diperlukan alat ukur emisi gas (Irvan dan Imam 2012).

Karbon monoksida adalah gas yang bersifat membunuh makhluk hidup termasuk manusia. Zat gas CO ini akan mengganggu pengikatan oksigen pada darah karena CO lebih mudah terikat oleh darah dibandingkan dengan oksigen dan gas-gas lainnya. Pada kasus

\footnotetext{
${ }^{1}$ Prodi Teknik Mesin Universitas Muhammadiyah Semarang
} 
darah yang tercemar karbon monoksida dalam kadar 70\% hingga 80\% dapat menyebabkan kematian pada orang (Taufan, 2014).

Hidrokarbon merupakan senyawa karbon yang paling sederhana. Menurut istilahnya, senyawa hidrokarbon adalah senyawa karbon yang hanya tersusun dari atom hidrogen dan atom karbon. Dalam kehidupan sehari-hari banyak kita temui senyawa hidrokarbon, misalnya minyak tanah, bensin, gas alam, plastik dan lain-lain (Ndie, 2009).

Penggunaan material Tembaga sebagai bahan pembuat filter gas buang kendaraan adalah langkah tepat. Menurut Amin M (2016) bahwa Tembaga dalam bentuk komposit yang dipergunakan sebagai filter gas emisi kendaraan memiliki potensi yang cukup baik dalam penurunan kadar gas emisi kendaraan tersebut.

\section{METODOLOGI}

Bahan yang dipergunakan dalam penelitian ini adalah menurut Gambar 1 yaitu:

1. Knalpot

2. Tembaga

3. Nikel

4. Mickroskop Optik

5. SEM

6. Gas Analiser
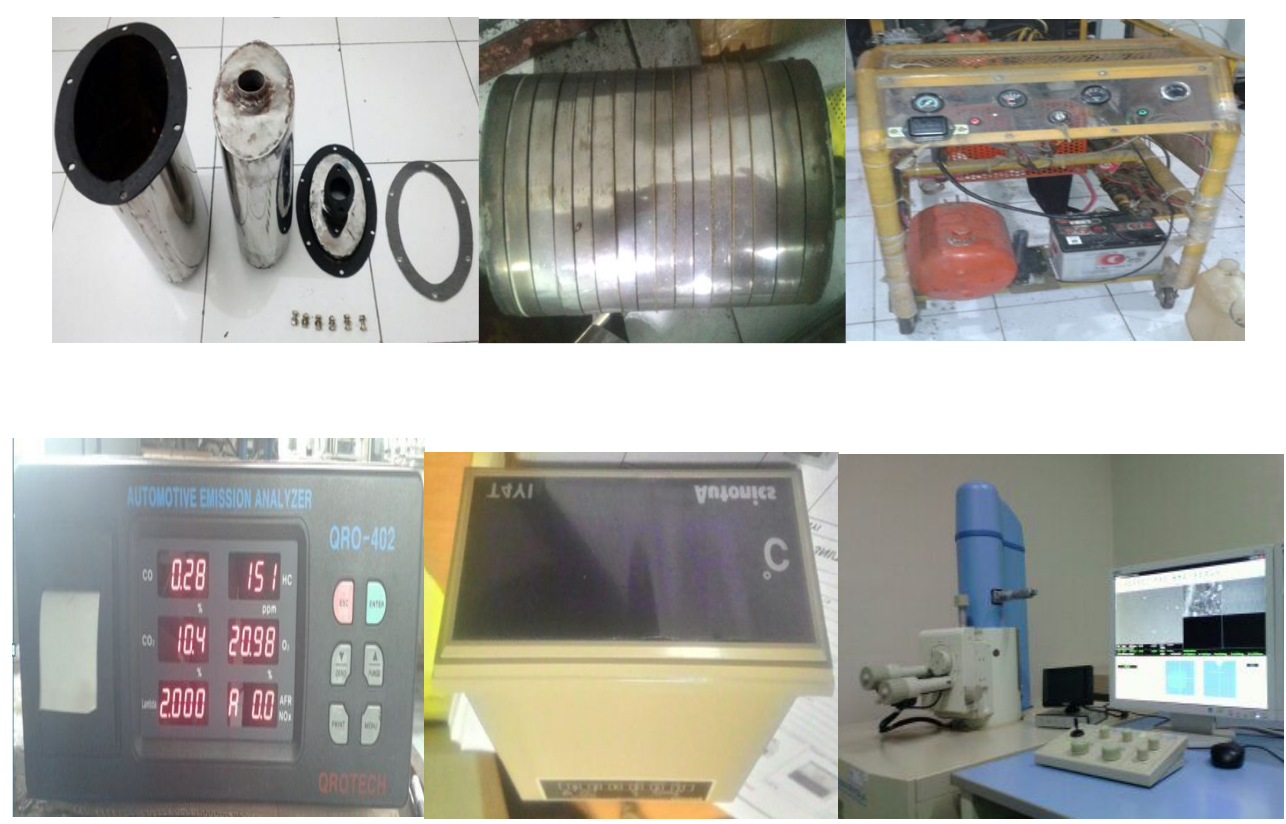

Gambar 1 Alat alat dalam penelitian. 


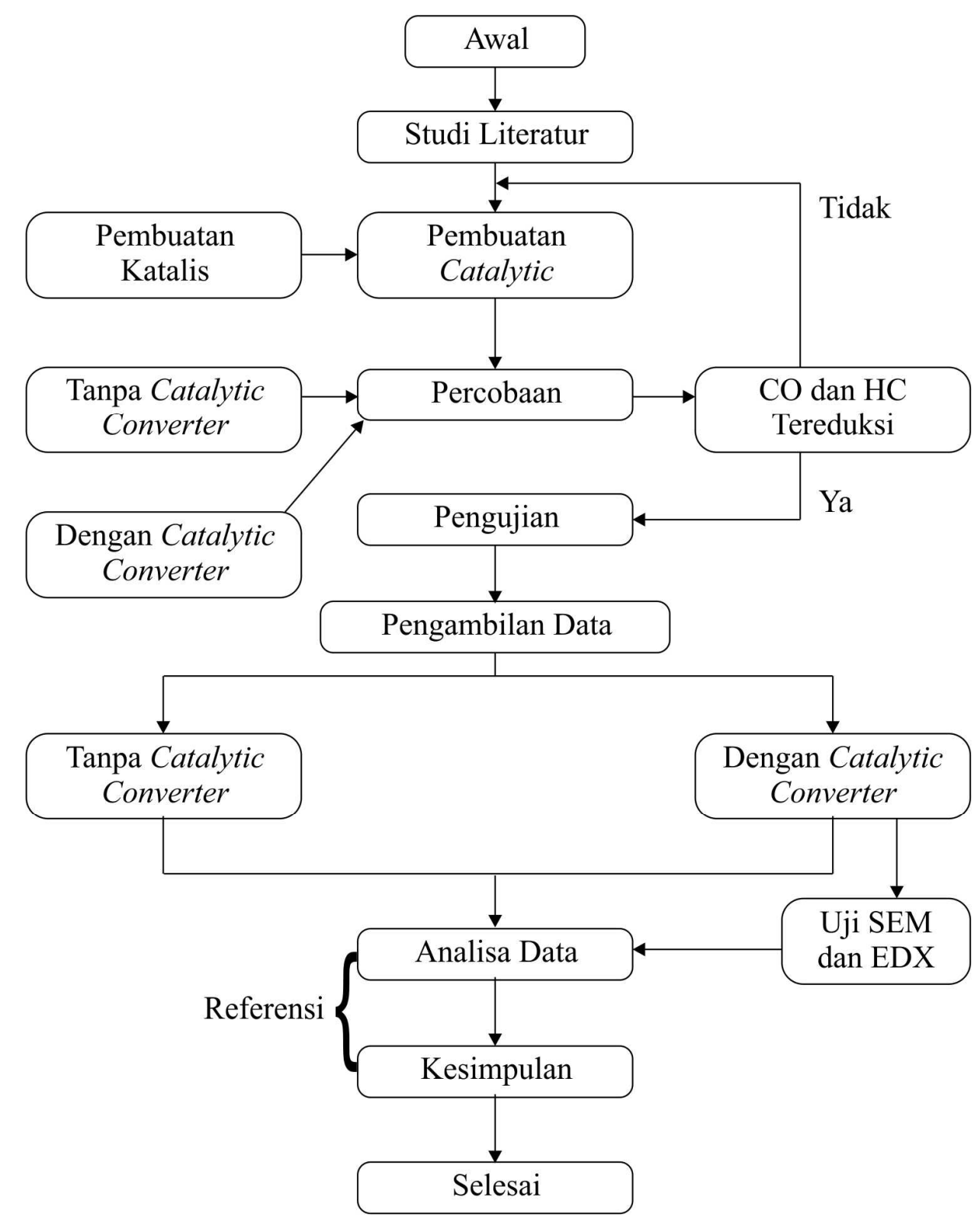

Gambar 2 Diagram alur metode penelitian

\section{HASIL DAN PEMBAHASAN}

\section{Hubungan Konsentrasi CO dengan Putaran Mesin pada Catalytic Converter 5 Katalis}

Pada Gambar 3 Pada putaran mesin 3000 pengujian tanpa katalis menunjukan konsentrasi $\mathrm{CO}$ sebesar $1 \%$, Sedangkan penggunaan 5 katalis $\mathrm{Cu}$ menunjukan konsentrasi $0,71 \%$ dan pada penggunaan 5 katalis $\mathrm{Cu}^{*} \mathrm{Ni}$ menunjukan konsentrasi $\mathrm{CO}$ dengan putaran mesin 3000 sebesar $0,7 \%$. 


\section{Hubungan Konsentrasi CO dengan Putaran Mesin pada Catalytic Converter 10 Katalis}

Pada putaran mesin $3000(\mathrm{Rpm})$ pengujian tanpa catalytic converter menunjukan konsentrasi $\mathrm{CO}$ sebesar $1 \%$, Sedangkan penggunaan catalytic converter katalis $10 \mathrm{Cu}$ menunjukan konsentrasi $1,57 \%$ dan pada penggunaan catalytic converter katalis $\mathrm{Cu} * \mathrm{Ni}$ menunjukan konsentrasi CO dengan putaran mesin 3000 (Rpm) sebesar $1 \%$.

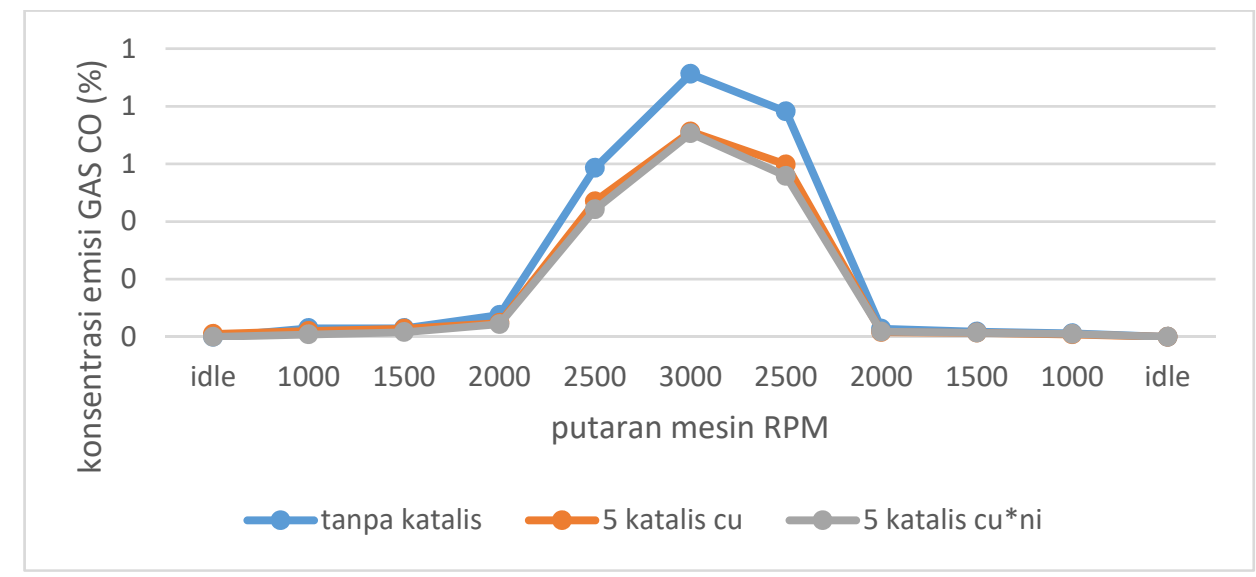

Gambar 3 Grafik 5 Katalis Catalytic Converter Terhadap Konsentrasi CO

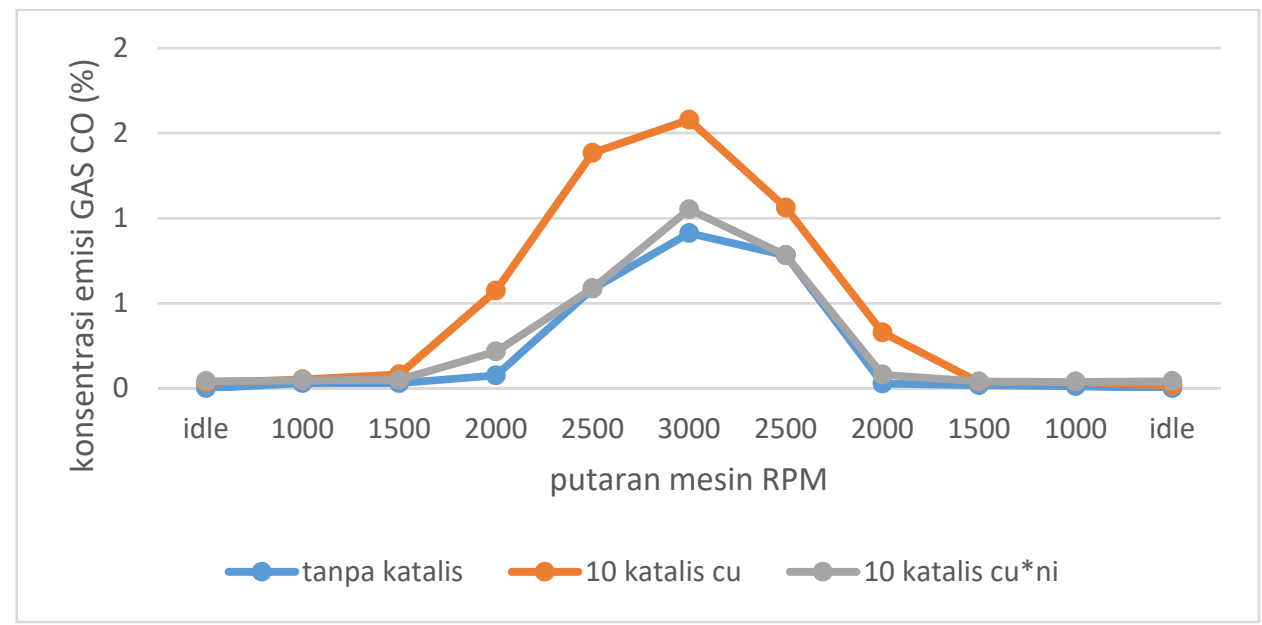

Gambar 4 Grafik 10 Katalis Catalytic Converter Terhadap Konsentrasi CO

\section{Hubungan Konsentrasi CO dengan Putaran Mesin pada Catalytic Converter 15 Katalis.}

Pada putaran mesin 3000 rpm catalytic converter $\mathrm{Cu} 15$ katalis menunjukkan konsentrasi sebesar 2,078 \% atau presentase kenaikan konsentrasi CO pada kondisi ini sebesar $52 \%$, sedangkan pada putaran mesin $3000 \mathrm{rpm}$ catalytic conberter $\mathrm{Cu}-\mathrm{Ni} 15$ katalis menunjukkan konsentrasi CO sebesar 1,66 \% atau presentase kenaikan sebesar $22 \%$. 


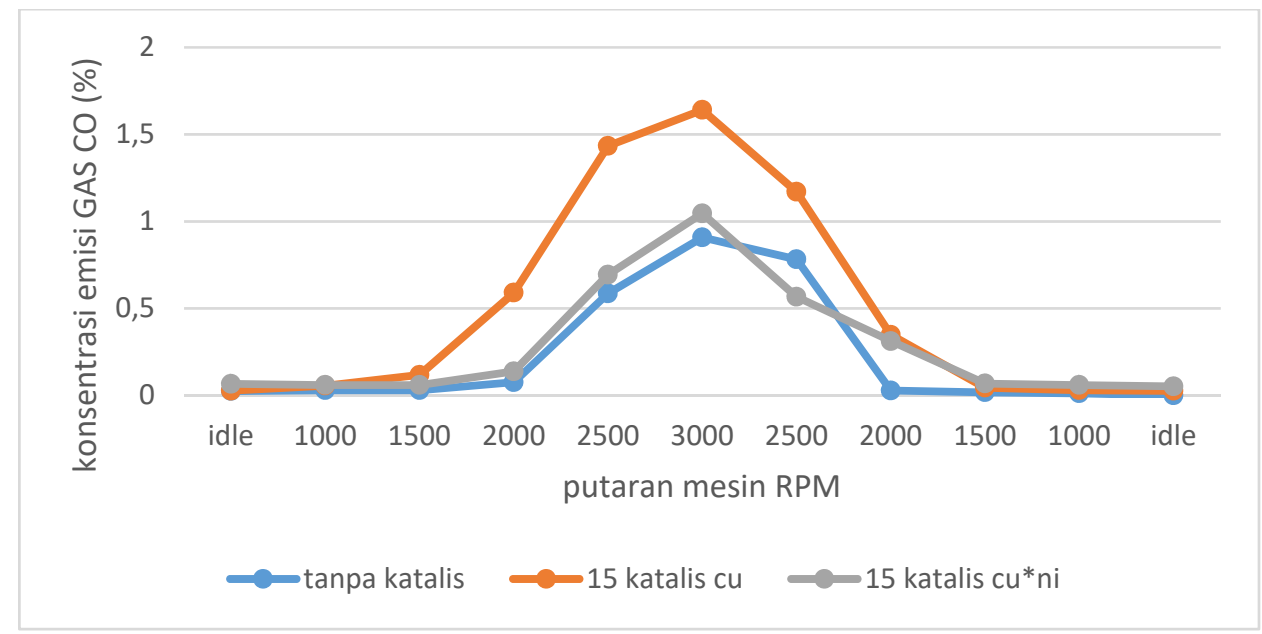

Gambar 5. Grafik 15 Katalis catalytic converter Terhadap Konsentrasi CO

\section{Hubungan Konsentrasi HC dengan Putaran Mesin pada Catalytic Converter 5 Katalis}

Pengujian tanpa catalytic converter akan digunakan sebagai acuan atas penurunan kosentrasi HC pada pengujian berikutnya baik pada saat menggunakan catalytic converter dengan variasi jumlah dan jenis katalis yang ditentukan.

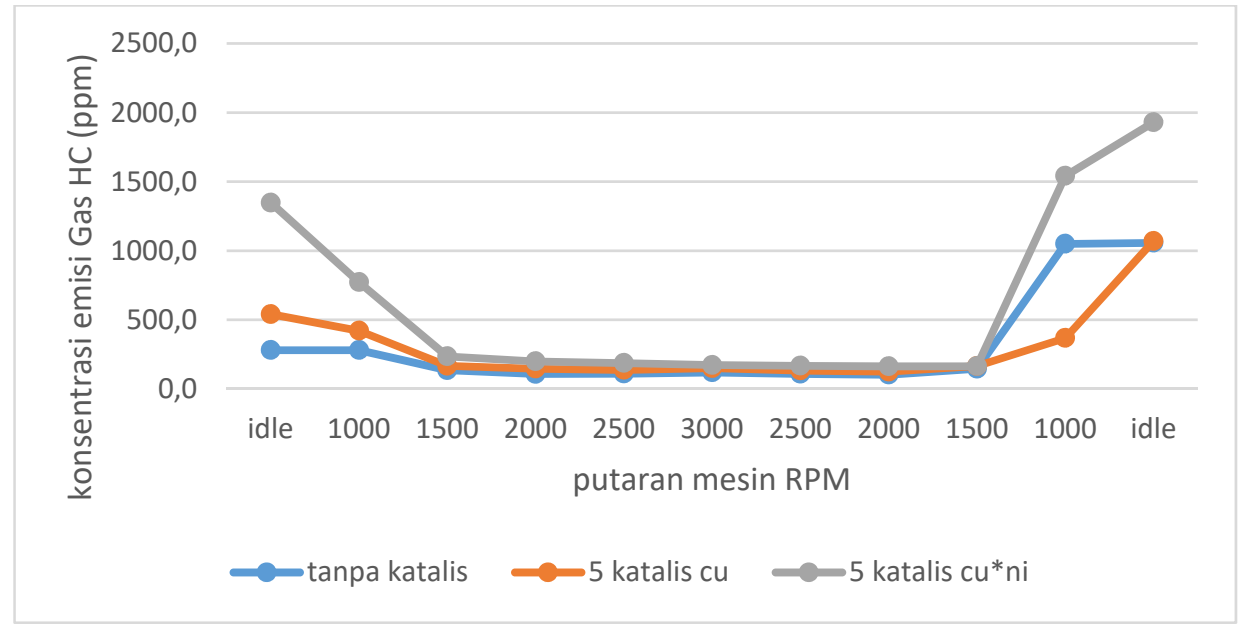

Gambar 6. Garfik 5 Katalis catalytic converter Terhadap Konsentrasi HC

Dari hasil pengujian konsentrasi HC tanpa catalytic converter akan digunakan sebagai acuan atas penurunan konsentrasi HC pada pengujian berikutnya baik pada saat menggunakan catalytic converter dengan variasi jumlah dan jenis katalis yang ditentukan.

Pada Gambar 6 menunjukan tiga perbandingan grafik penurunan konsentrasi HC, pada idle (900 Rpm) pengujian tanpa catalytic converter menunjukan konsentrasi HC sebesar 304,1 ppm. Penggunaan 5 katalis Cu pada catalytic converter menunjukan konsentrasi 1347,8 ppm. Atau dengan kata lain dapat meningkatkan emisi sebesar $343 \%$ pada putaran mesin 
$1000(\mathrm{Rpm})$ akhir. Penurunan konsentrasi $\mathrm{HC}$ pada catalytic converter $\mathrm{Cu} * \mathrm{Ni} 5$ katalis sebesar 78,5 \% dengan kadar HC 541 ppm pada putaran mesin 1000 (Rpm) akhir.

\section{Hubungan Konsentrasi HC dengan Putaran Mesin pada Catalytic Converter 10 Katalis}

Berdasarkan Gambar 7, penurunan konsentrasi $\mathrm{HC}$ catalytic converter $\mathrm{Cu} 10$ katalis sebesar $168 \%$ dengan kadar 816 ppm pada putaran mesin Idle (900 Rpm) awal. Berbeda dengan grafik catalytic converter $\mathrm{Cu}^{*} \mathrm{Ni} 10$ katalis bahwa penurunan konsentrasi $\mathrm{HC}$ tertingi sebesar $26 \%$ pada putaran idle (900 Rpm) akhir dengan kadar HC sebesar 381,8 ppm.

Dari grafik menunjukkan bahwa emisi gas HC secara keseluruhan mengalami penurunan konsentrasi pada setiap variasi putaran. Penurunan konsentrasi HC setiap perubahan Rpm mengalami fluktuasi yang berbeda-beda, hal ini disebabkan karena jumlah bahan bakar yang masuk ke dalam ruang bakar setiap perubahan Rpm berbeda-beda. Disamping itu campuran bahan bakar yang masuk juga dipengaruhi oleh kondisi kendaraan uji (Irawan B., Dan Subri M., 2005).

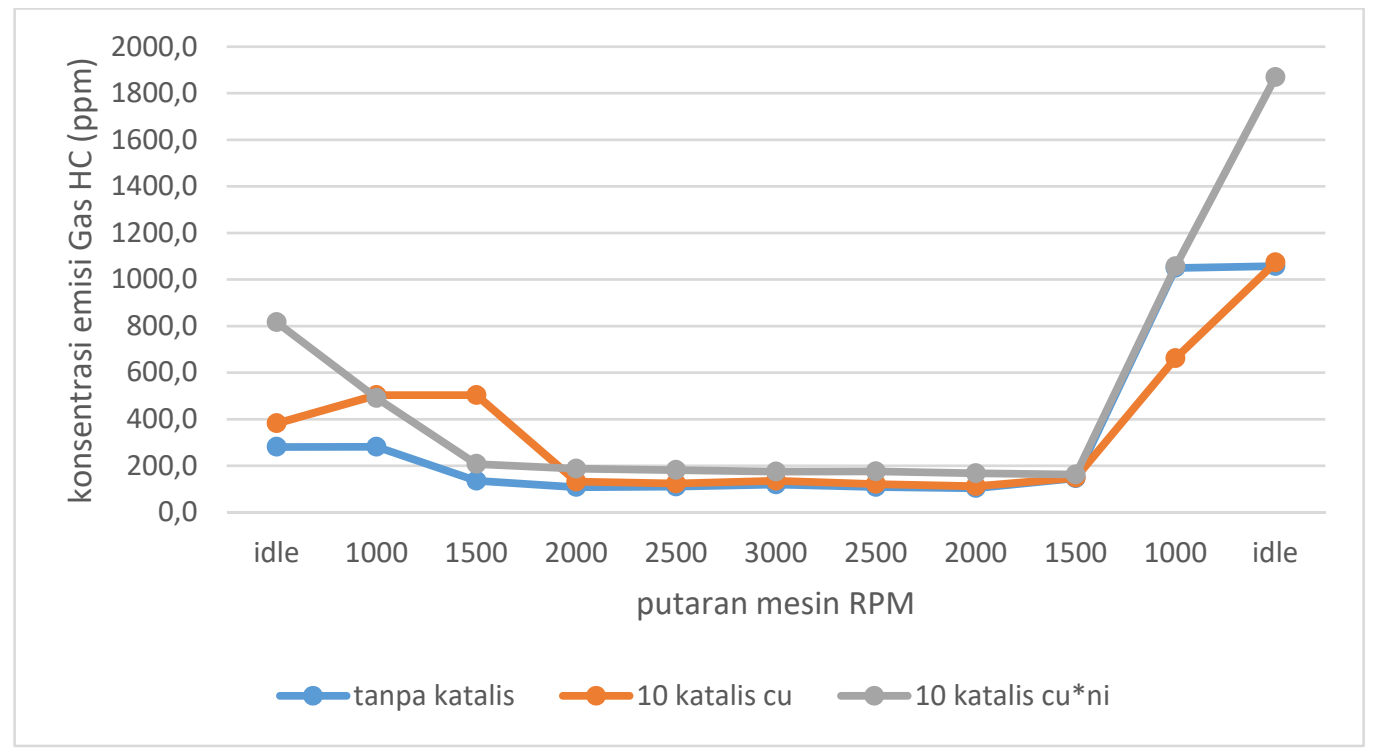

Gambar 7. Grafik 10 Katalis catalytic converter Terhadap Konsentrasi HC

\section{Hubungan Konsentrasi HC dengan Putaran Mesin pada Catalytic Converter 15 Katalis}

Pada Gambar 8 menunjukkan penurunan tertinggi konsentrasi HC catalytic converter $\mathrm{Cu} 15$ katalis sebesar $37 \%$ pada putaran mesin idle (900 Rpm) di awal pengujian dengan konsentrasi HC 190,2 ppm. 


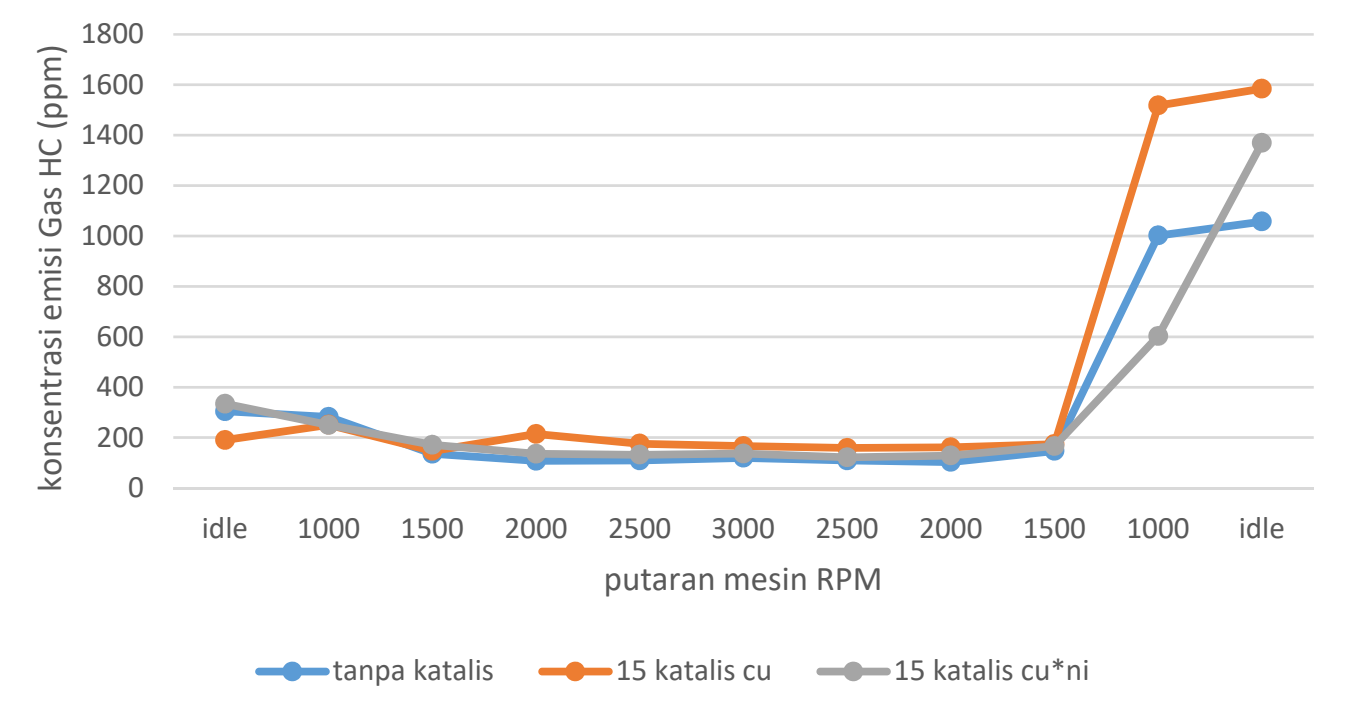

Gambar 8. Grafik 15 Katalis Catalytic Converter Terhadap Konsentrasi HC

Dari gambar 8 terlihat bahwa penurunan emisi HC dipengaruhi juga oleh jumlah sel yang terpasang pada catalytic converter. Namum pada penambahan katalis 15 sel terlihat bahwa $\mathrm{HC}$ cenderung lebih tinggi dari katalis 10 Sel. Ini dapat terjadi akibat kondisi mesin uji yang bertambah panas dan jumlah bahan bakar yang masuk ke ruang bakar. Meski demikian. Ada kecenderungan semakin banyak sel penurunan emisi menjadi lebih tinggi (Irawan B Dan Subri M, 2005).

\section{Karakterisasi Material Sebelum dan Sesudah Pemakaian}

Untuk mengetahui karakteristik material katalis $\mathrm{Cu}$ dan $\mathrm{Cu}-\mathrm{Ni}$ maka dilakukan pengujian SEM dan EDX pada substrat katalis sebelum dan sesudah dilakukan pemakaian pada engine stand.

\section{Pengujian SEM Sebelum Pemakaian}

Hasil dari SEM pada sample dan berdasarkan hasil search and match menggunakan data tersebut adalah puncak dari nikel (Ni), sehingga nikel (Ni) tidak bereaksi dengan oksigen dari udara membentuk NiO, tetapi tetap berdiri sendiri sebagai Ni. Sedang arang karbon terbakar dan lepas pada temperatur tinggi sehingga meninggalkan rongga pori, karena diruang bakar dialirkan gas nitrogen unsur $\mathrm{C}$ tertinggal sebagai residu tidak bereaksi dengan $\mathrm{O}_{2}$, demikian pula PVA pada temperatur diatas $250^{\circ} \mathrm{C}$ terbakar dan meninggalkan lubang pori, gas $\mathrm{H}_{2}$ menguap dan unsur $\mathrm{C}$ tertinggal menjadi residu. 
Keberadaan sedikit ruang kosong akan mempengaruhi kerapatan kepadatan berpori sehingga akan mempengaruhi terhadap perbandingan dari berat per volume. Nikel (Ni) berpori nilai densitas cenderung bertambah dengan kenaikan komposisi nikel (Ni), hal ini karena partikel-partikel nikel (Ni) berpori, porositas dimaksudkan untuk membuat luas permukaan menjadi besar pada luas geometri yang sama. Keberasaan porositas ini pada temperatur tinggi menjadi gas $\mathrm{CO}$ dan $\mathrm{CO}_{2}$ terperangkap diantara butiran nikel $(\mathrm{Ni})$, pada saat pemadatan, partikel sering merapat, mengikat dan mengeras. Nampak bahwa dengan bertambahnya komposisi nikel (Ni) maka porositas bertambah kecil. Hal ini karena pada temperatur tinggi pemadatan terjadi, partikel mengecil dan saling merapat dan memadat.

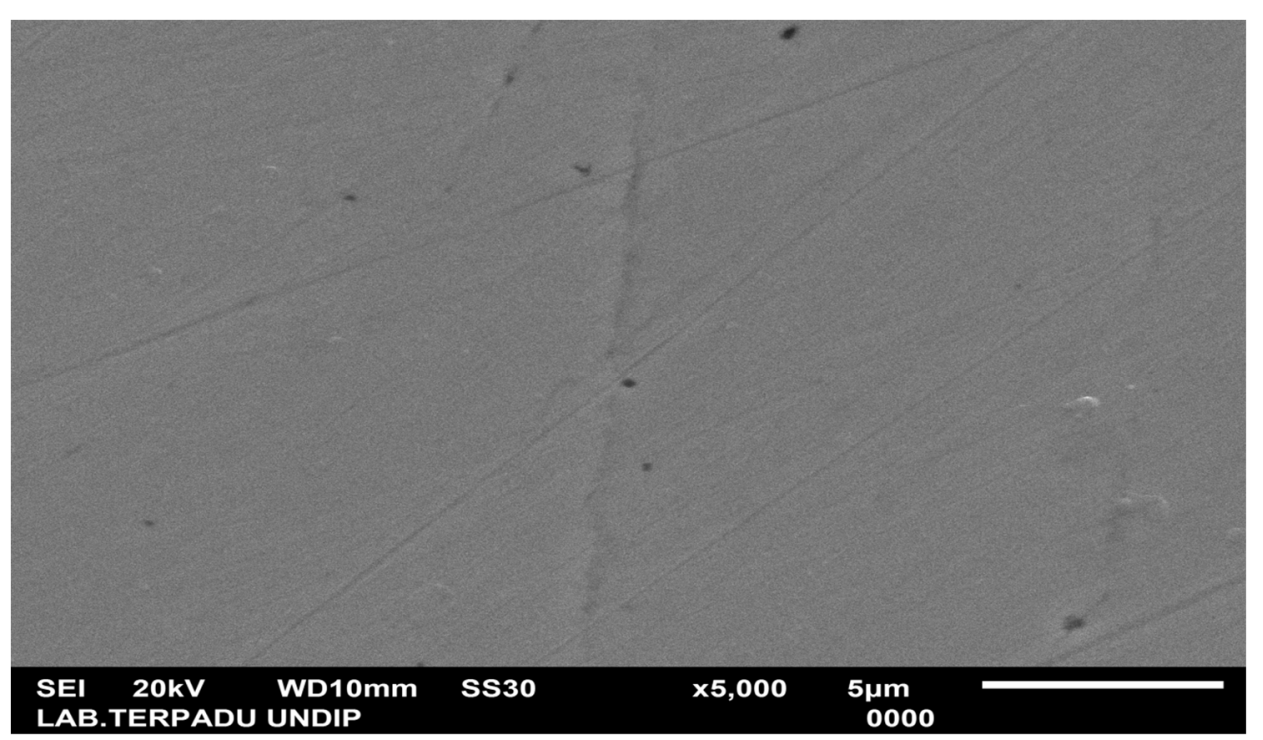

Gambar 9 Karakteristik Permukaan Material Katalis Cu-Ni Sebelum Pemakaian

\section{Pengujian SEM Setelah Pemakaian}

Struktur mikro dari sampel nikel (Ni) berpori dengan variasi bahan nikel diamati mempergunakan SEM yang hasilnya ditampilkan pada Gambar 10 dengan perbesaran $5000 \mathrm{x}$. Analisa SEM ini menampilakan morfologi partikel yang terbentuk karena proses pembakaran. Pada Gambar 10 menunjukkan perbedaan komposisi campuran nikel (Ni). Dari Gambar nampak bahwa bagian berwarna hitam adalah porositas yang terbentuk dari sampel. Sedang warna abu-abu adalah partikel nikel (Ni). Arang karbon dan PVA berubah menjadi gas $\mathrm{CO}$ dan $\mathrm{CO}_{2}$ membentuk rongga pori. 


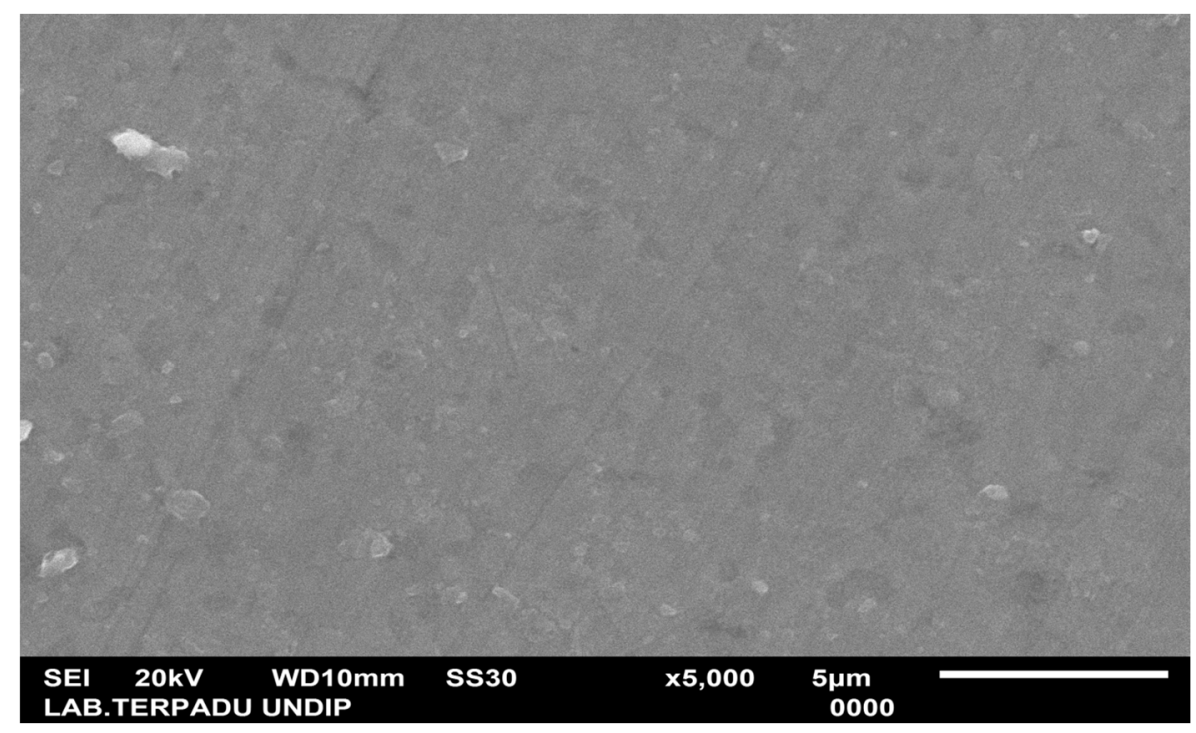

Gambar 10 Karakteristik Permukaan Material Katalis Cu-Ni Setelah Pemakaian

\section{Pengujian Crosektion (Ketebalan Lapisan) Material Katalis Cu-Ni Sebelum Pengujian}

Pengujian crosektion ini dilakukan untuk mengetahui tebal lapisan yang terdapat pada sampel agar lebih jelas dilakukan pembesaran X500.

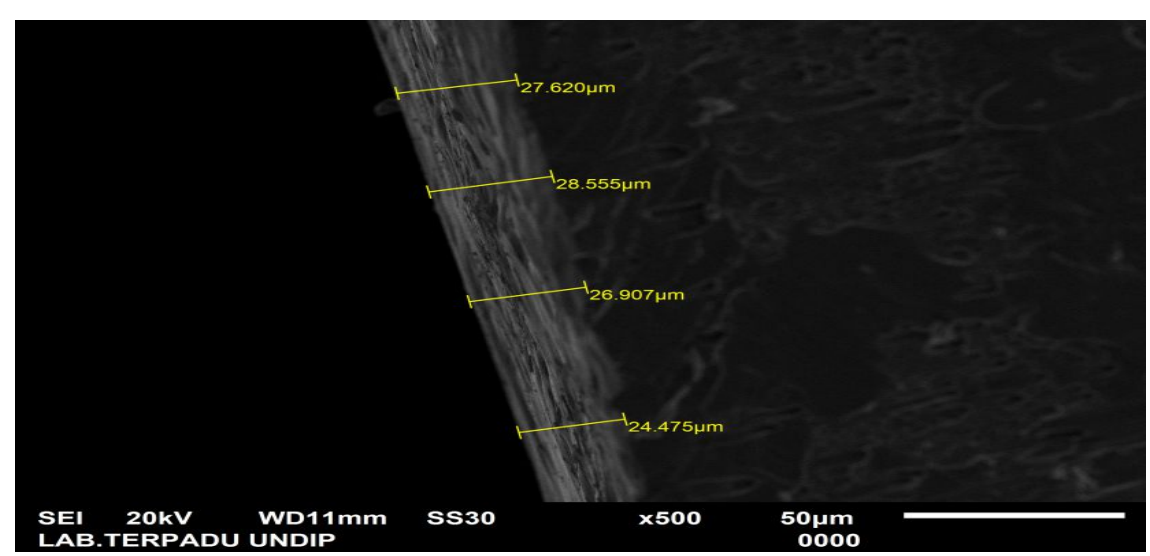

Gambar 11 Foto Hasil Crosektion Cu-Ni Sebelum Pemakaian

Terlihat pada Gambar 11 bahwa adanya rongga yang terdapat pada lapisan nikel dan penyusutan lapisan nikel (Ni) sehingga dalam pengukuran terjadi perbedaan disetiap titik pengukuran. Hal tersebut terjadi karena terikatnya partikel yang memadat dari hasil pelapisan.

\section{Pengujian Crosektion (Ketebalan Lapisan) Material Katalis Cu-Ni Setelah Pengujian}

Pengujian ini dilakukan untuk mengetahui struktur mikro dari bahan katalis tembag $(\mathrm{Cu})$ yang sudah dilapisi nikel $(\mathrm{Ni})$ setelah adanya proses pembakaran yang dilakukan melalui engine stand sebagai benda pengujinya. 


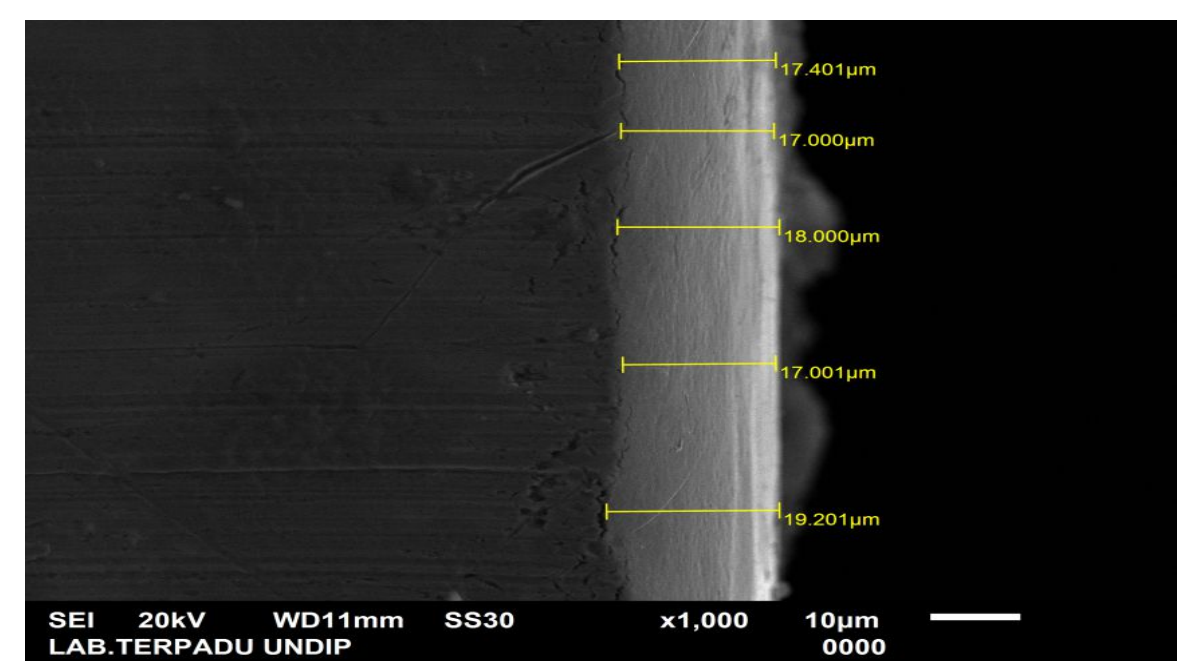

Gambar 12 Foto Hasil Crosektion Cu-Ni Setelah Pemakaian

Pada Gambar 12 menunjukan terjadinya penyusutan ketebalan lapisan di karenakan keberadaan sedikitnya ruang kosong mempengaruhi kerapatan dan kepadatan. Hal ini dikarenankan temperatur tinggi dan juga adanya tekanan sehingga pemadatan terjadi. Dengan temperatur dan tekanan tinggi selain adanya pemadatan terbentuklah rongga antara tembaga $(\mathrm{Cu})$ dan nikel $(\mathrm{Ni})$.

\section{Pengujian EDX Sebelum Pengujian}

Hasil pengujian EDX yang telah dilakukan peneliti pada spesimen uji bahan katalis sebelum dilakukan pengujian emisi gas buang ditunjukkan dengan metode grafis seperti yang ditunjukkan pada Gambar 13.

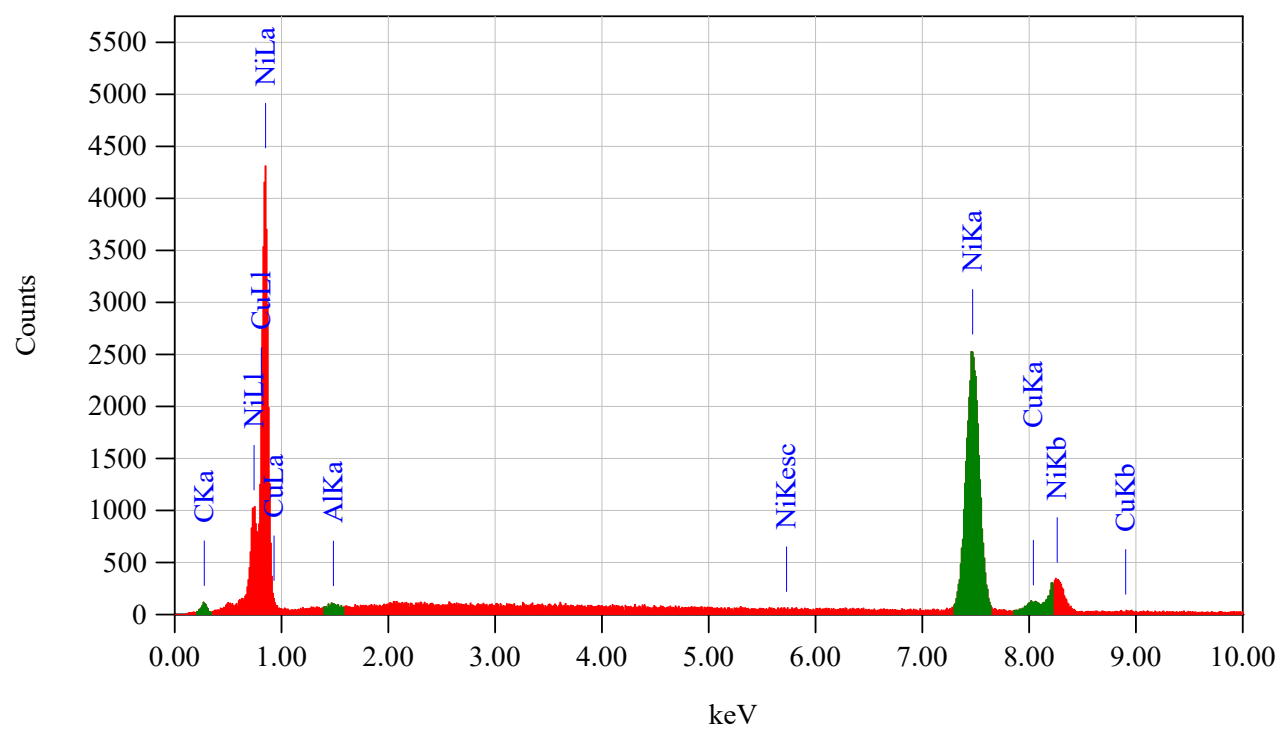

Gambar 13 Grafik Pengujian EDX Material Katalis Cu-Ni Sebelum Pemakaian. 
Berdasarkan Gambar 13 terlihat perbandingan element parameter untuk carbon (CK) massa $6,68 \%$, sigma 0,18 , mol $30.90 \%$ dan compound massa 6,68\%, cation 0 , kalium 1,5911, oksigen massa 20,07 \%, nikel massa 70,04\%, sigma 0,66, mol $66.26 \%$, dan compound massa 89,14\%, cation 22,83 \% atau Gambar komponen logam lebih jelas pada Tabel 4.1

\section{Pengujian EDX Setelah Pengujian}

Berdasarkan Gambar 14 menunjukkan hasil pengujian EDX pada spesimen uji bahan katalis setelah pemakaian spesimen tersebut dalam pengujian emisi gas buang dan disajikan dalam bentuk grafis.

Tabel 1 Pengujian EDX Material Katalis Cu-Ni Sebelum Pengujian

\begin{tabular}{|l|c|c|c|c|c|c|c|c|}
\hline Element & (kev) & Mass \% & Sigma & Mol \% & Compound & Mass \% & Cation & K \\
\hline CK & 0,277 & 6.68 & 0.18 & 30.90 & $\mathrm{C}$ & 6.68 & 0.00 & 1.5911 \\
\hline $\mathrm{O}$ & - & 20.07 & - & - & - & - & - & - \\
\hline $\mathrm{A} 1 \mathrm{~K}$ & 1.486 & 0.27 & 0.07 & 0.28 & $\mathrm{~A} 1203$ & 0.51 & 0.19 & 0.1404 \\
\hline $\mathrm{Ni} \mathrm{K}$ & 7.471 & 70.04 & 0.66 & 66.26 & $\mathrm{Ni} 0$ & 89.14 & 22.83 & 94.5092 \\
\hline $\mathrm{Cu} \mathrm{K}$ & 8.040 & 2.93 & 0.17 & 2.56 & $\mathrm{Cu} 0$ & 3.67 & 0.88 & 3.7592 \\
\hline Total & - & 100.00 & - & 100.00 & - & 100.00 & 23.90 & - \\
\hline
\end{tabular}

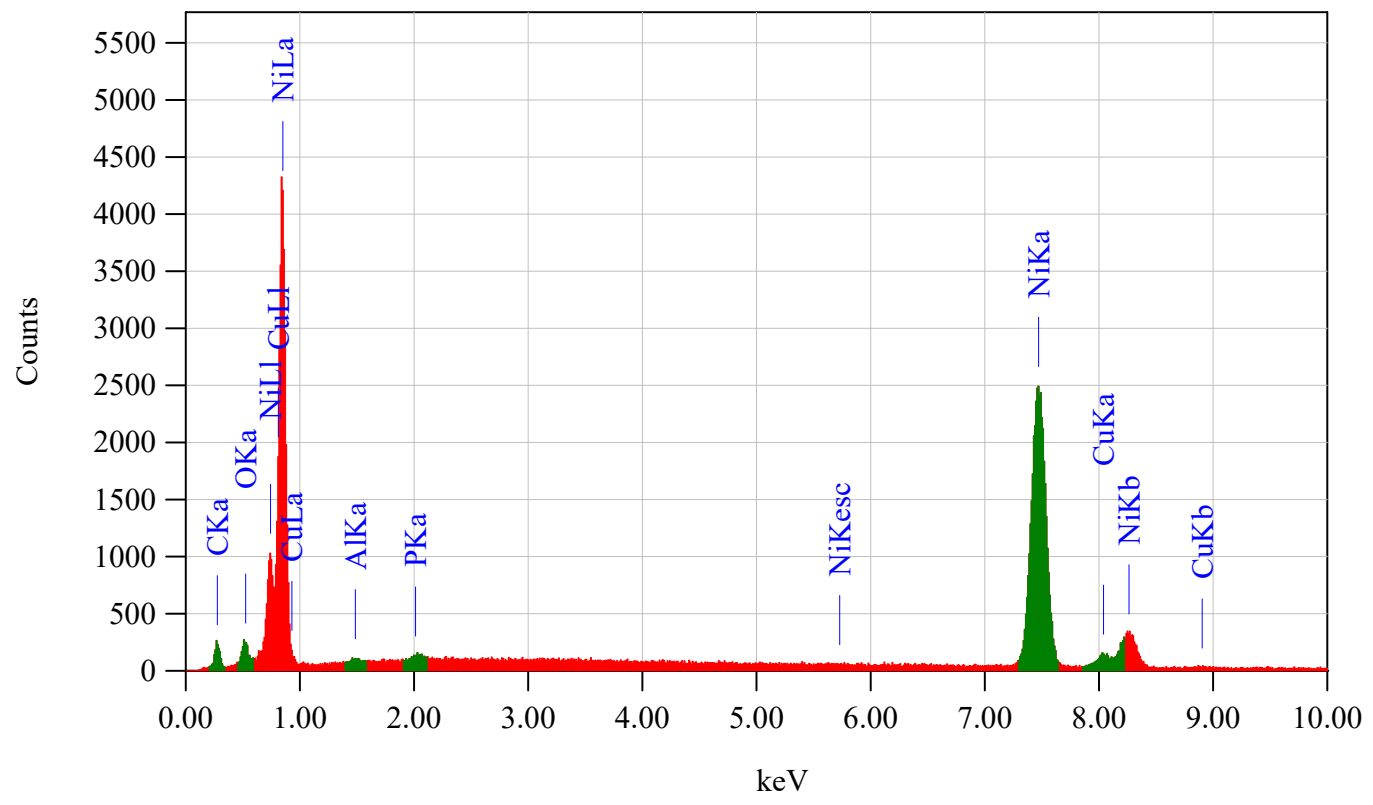

Gambar 14 Grafik Pengujian EDX Material Katalis Cu-Ni Setelah Pemakian 
Tabel 2 Pengujian EDX Material Katalis Cu-Ni Setelah Pemakaian

\begin{tabular}{|l|c|c|c|c|c|c|c|c|}
\hline Element & (kev) & Mass \% & Sigma & Mol \% & Compound & Mass \% & Cation & K \\
\hline $\mathrm{CK}$ & 0.277 & 13.70 & 0.24 & 49.83 & $\mathrm{C}$ & 13.70 & 0.00 & 3.6028 \\
\hline $\mathrm{O}$ & - & 18,68 & - & - & - & - & - & - \\
\hline $\mathrm{A} 1 \mathrm{~K}$ & 1.486 & 0.19 & 0.06 & 0.15 & $\mathrm{~A} 12 \mathrm{O} 3$ & 0.36 & 0.14 & 0.1073 \\
\hline $\mathrm{P} \mathrm{K}$ & 2.013 & 0.19 & 0.06 & 0.14 & $\mathrm{P} 2 \mathrm{O} 5$ & 0.44 & 0.13 & 0.1768 \\
\hline $\mathrm{Ni} \mathrm{K}$ & 7.471 & 64.24 & 0.60 & 47.82 & $\mathrm{NiO}$ & 81.75 & 22.49 & 92.0281 \\
\hline $\mathrm{Cu} \mathrm{K}$ & 8.040 & 3.00 & 0.16 & 2.06 & $\mathrm{NiO}$ & 3.76 & 0.97 & 4.0850 \\
\hline Total & - & 100.00 & - & 100.00 & - & 100.00 & 23.74 & - \\
\hline
\end{tabular}

Pada Gambar 14 diatas menunjukan perbandingan element parameter untuk carbon (CK) massa 13,70 \%, sigma 0,24, mol 48,83\% dan compound massa $13.70 \%$, cation 0 , kalium 3,6028, oksigen massa $18,68 \%$, nikel massa $64,24 \%$, sigma 0,60 , mol 47,82 \%, dan compound massa 81,75 \%, cation 22,49 \% atau Gambar komponen logam terlihat lebih jelas pada Tabel 2.

\section{DAFTAR PUSTAKA}

Agus M. 2012, “Analisis prinsip kerja Catalytic Converter”

Amin M, 2006, Uji Performa Filter Gas Emisi Kendaraan Bermotor Berbasis Keramik Porous Dengan Aditif Tembaga, Tio2 Dan Karbon Aktif Dalam Penurunan Kadar Gas Carbon Monoksida, Jurnal MEKANIKA Vol 15 No. 2 Tahun 2016, ISSN: 1412-7962 - $\quad$ e-ISSN: 2579-3144.

https://Jurnal.Ft.Uns.Ac.Id/Index.Php/Mekanika/Article/View/418

Dowden, at all, 1970, Catalytic Hand Book, Verlag New York, Inc.

Irawan, B. 2003. "Unjuk Kerja Catalytic Converter Tembaga (Cu) Pada Saluran Gas Buang Kendaraan Bermotor Untuk Mereduksi Emisi Gas Carbon Monoksida.” Program Magister Ilmu Lingkungan. Semarang, Universitas Diponegoro.

Irawan,. B., dan Subri, M., 2005, “Unjuk Kemampuan Catalytic Converter dengan Katalis Kuningan untuk Mereduksi Gas Hidrokarbon Motor Bensin,” Traksi Vol. 03 No. 02. Semarang: Universitas Muhammadiyah Semarang.

Irawan, B., Purwanto., dan Hadiyanto, 2013. "Unjuk Kemampuan Katalis Tembaga Berlapis Mangan Dalam Mengurangi Emisi Gas Carbon Monoksida Motor.

Ismiyati., 2012, "Penyebab pencemaran udara Akibat Emisi Gas Buang" Universitas Muhammadyiyah Jakarta. 
Irvan Adi, dan Imam Abadi,. "Rancang Bangun Alat Ukur Emisi Gas Buang" Jalius Jama. 2008, "Siklus Kerja Motor Bakar"

Joko Winarno., 2014, "Studi Emisi Gas Buang Kendaraan Bermesin Bensin Pada Berbagai Merk Kendaraan dan Tahun Pembuatan," Staf Pengajar Jurusan Teknik Mesin Fakultas Teknik Universitas Janabadra.

Pamungkas anto.,2015, "Emisi gas Buang sebagai pencemaran udara paling mendominasi” Ramdani., 2015, “Unsur Susunan Udara kering” Politeknik Negri Sriwijaya.

Subri, M. 2012. "Kaji Experimental Pengaruh Bentuk Geometri Sudut Converging Duct dan Panjang Constant Area Section pada Perfoma Sistem Refrigerasi Steam Ejektor.” Mechanical Engineering. Semarang, Universitas Diponegoro.

Syahrani, A. 2006. “Analisa Kinerja Mesin Bensin Berdasarkan Hasil Uji Emisi.” Jurnal SMARTek, Volume 4. Nomor 4: 260 - 266.

Tri Tugaswati. "Emisi gas Buang Kendaraan Bermotor dan Dampak Emisi Gas Buang Terhadap Kesehatan"

Wardhana, W. A., 2004. "Dampak Pencemaran Lingkungan. Yogyakarta," Andi Yogyakarta.http://www.psychologymania.com/2012/08/pencemaran-udara-akibatkendaraan.html

Wardhana, Wisnu Arya. (2001). “Dampak Pencemaran Lingkungan”. http://pengentau.weebly.com/karbon-monoksida.html

Warju., dan I Made Muliatna., "Unjuk Kemampuan Metallic Catalytic Converter Tembaga Terhadap Reduksi Emisi Gas Buang Sepeda Motor Yamaha Vega,” Fakultas Tenik, Universitas Negeri Surabaya (UNESA).

White, 1986. “Mekanika Fluida,” Jakarta, Erlangga. Jilid 1.

PENULIS:

\section{SUNAN BUKHORI IKHWAN NASRULLAH}

Teknik Mesin - Fakultas Teknik - Universitas Muhammadiyah Semarang

Jl. Kasipah no.12 Semarang 50254

E-mail : sunantroops06@gmail.com 